\title{
MODEL TEACHERPRENEUR PADA PEMBELAJARAN VOKASI MENGHADAPI ERA DISRUPSI DAN REVOLUSI INDUSTRI 4.0
}

\author{
Wisnu Rachmad Prihadi \\ Pendidikan Teknik Sipil dan Perencanaan, FT, UNY \\ E-mail: wisnurachmadprihadi@uny.ac.id
}

\begin{abstract}
This study aims: (1) to examine the grand design of the teacherpreneur model in vocational education on the development of the industrial revolution and disruption. This research uses descriptive method based on literature review. The results of the study show that: The teacherpreneur model for preparing learning in the industrial revolution 4.0 era that was developed was composed of four pillars namely competency, creativity, effectiveness, collaboration. needed the addition of a pillar of collaboration as a time of growing rapidly. In this model it is necessary to retest both internally related to the effectiveness of the model before it is applied. although it can be seen at the beginning for the initial model that has a pretty good score, i.e. (a) the model components are complete (92.83\%); (b) the structure of the model components is clear (91.65\%); (c) the relationship between the components of the model is clear (95.83\%); (d) the model readability has been good (95.83\%); (e) the model is feasible (95.83\%); and (f) effective models if implemented (87.5\%).
\end{abstract}

Keywords: development, pilars, teacherpreneur

\begin{abstract}
ABSTRAK
Kajian ini bertujuan: (1) mengkaji grand design model teacherpreneur pada pendidikan kejuruan terhadap perkembangan revolusi industri dan disrupsi. Penelitian ini menggunakan metode deskriptif berdasarkan kajian literatur. Hasil kajian menunjukkan bahwa: Model teacherpreneur untuk menyiapkan pembelajran di era revolusi industri 4.0 yang dikembangkan tersusun atas empat pilar yaitu kompetensi, kreatifitas, efektivitas, kolaborasi. diperlukan penambahan pilar kolaborasi sebagai tutntutan zaman yang begitu berkembang pesat. Pada model ini perlunya dilakukan pengujian ulang baik secara internal terkait keefektifan model sebelum diterapkan. walapun dapat dilihat diawal untuk model awal memiliki skor yang cukup baik yaitu (a) komponen model telah lengkap (92,83\%); (b) struktur komponen model telah jelas (91,65\%); (c) hubungan antar komponen model telah jelas (95,83\%); (d) keterbacaan model telah baik (95,83\%); (e) model telah layak (95,83\%); dan (f) model efektif jika diimplementasikan (87,5\%).
\end{abstract}

Kata Kunci: pengembangan, pilar, teacherpreneur

\section{PENDAHULUAN}

Permasalahan Revolusi Industri Generasi Empat (R.I 4.0 ) sudah menjadi perbincangan keseharian dimasyarakat luas, khususnya dilingkungan akademisi dan industri. Perkembangan R.I 4.0 yang telah berkembang cepat merambah diberbagai lini kehidupan dan menjadikan dasar penentu keputusan yang berkaitan dengan kebijakan ekonomi dan industri. Hal ini dapat kita rasakan bersama dengan pemanfaatan teknologi yang sangat sederhana menjadi sangat berarti contohnya aplikasi ojek online. Konsep yang semula tukang ojek yang hanya dapat ditemukan di pangkalan ojek saja kemudian dikemas dan dikolaborasikan dengan teknologi yang berbasis aplikasi smartphone dan dilengkapi dengan berbagai tambahan fitur yang dibutuhkan oleh semua orang menjadikan ojek online aplikasi yang dibutuhkan bagi semua orang.

Melihat fenomena ojek online yang merupakan hasil dari perkembangan Revolusi Industri memberikan inovasi yang berdampak luas serta melahirkan tren baru dan disrupsi. Istilah distrupsi dijelaskan oleh Klause Schwab (2017) dalam tulisan berjudul The Fourth Industrial Revolution terkait kesadaran para 
industriawan dan pengusaha diseluruh dunia akan pentingnya menaruh perhatian pada dampak yang diakibatkan dari perkembangan revolusi industri generasi yang menimbulkan potensi inovasi dan kerusakan. Dikatakan inovasi karena mengemas dan memudahkan berbagai urusan menjadi lebih mudah dan menarik dari konvensional. Dikatakan kerusakan artinya merupakan ancaman bagi keberlangsungan dan kemapanan suatu usaha atau industri yang telah mengalami perubahan, yang diistilahkan sebagai distruptive innovation (Sutarto, 2019).

Distruptive innovation dijelaskan oleh Clayton M Cristensen \& Joseph Bower lebih dari dua dekade silam, dimana dalam jurnal Harvard Business Review tahun 1995 dengan judul "Disruptive Technologies : catching the wave" yaitu inovasi baru yang merusak inovasi yang lama yang dapat menghancurkan dunia industri yang telah mapan. Hal ini dapat dicontohkan dan bahkan dialami oleh orang tua kita seperti munculnya komputer yang menggantikan mesin ketik, wikipedia yang merusak bisnis kamus dan buku ensikopedia, perusahaan CD dan USB yang menghancurkan perusahaan floppy disk atau kaset, Mall dan pusat perbelanjaan yang beralih ke virtual mall. Meskipun terdapat juga inovasi yang tidak terdisrupsi, tetapi justru mengalami penguatan atau yang diistilahkan sustaining innovation misalnya e-banking, industri jasa pengiriman (Shiping) dan termasuk juga ojek online. Hal ini karena Inovasi yang dilakukan mengemas dan menguatkan inovasi lama dan bahkan berkembang secara sporadis.

Menyikapi R.I. 4.0 pemerintah menyiapkan strategi dan memberikan perhatian kepada SMK dalam menghadapi perubahan teknologi yang terjadi dengan melakukan revitalisasi SMK yang dituang dalam Inpres nomor 9 tahun 2016. Kebijakan Inpres nomor 9 tahun 2016 bertujuan untuk meningkatkan daya saing dan kualitas sumber daya manusia (SDM) yang dihasilkan. Program revitalisasi yang disaksikan langsung 34 kepala daerah, kepala
BNSP dan dihadapan 12 Menteri Kabinet Kerja bertujuan untuk melaksanakan penyusunan peta kebutuhan tenaga kerja lulusan SMK dan mempercepat sertifikasi kompetensi lulusan SMK, pendidik dan tenaga kependidikan SMK untuk memiliki pengakuan yang terstandarisasi sesuai bidang keahlian yang dimiliki. Diundangnya kepala daerah secara khusus memberi tugas untuk melakukan penataan kelembagaan SMK yang mencakup program kejuruan yang dibuka dan lokasi SMK, mengembangkan SMK unggulan dan memberikan kemudahan kepada masyarakat untuk mendapat layanan pendidikan SMK sesuai potensi wilayah masing-masing. Tugas inilah yang harus benar-benar dicermati untuk melihat SMK dari sisi perannya terhadap pembangunan daerah dengan mengembangkan dan memanfaatkan potensi lokal untuk kesejahteraan masyarakat.

Menyiapkan SDM lulusan SMK yang benar-benar dapat berkiprah dan bersaing di era R.I 4.0 tentulah membutuhkan perancangan sedemikian rupa secara holistik dan komprehensif meliputi seluruh elemen dalam berlangsungya proses pembelajaran di SMK atau sekolah vokasi lainnya. Penyelarasan pembelajaran vokasi untuk R.I 4.0 diperlukan untuk menjembatani kondisi tenaga kerja saat ini dengan peningkatan atas perubahan kebutuhan kompetensi tenaga kerja. Penyelarasan pembelajaran vokasi untuk RI 4.0 merupakan salah satu jawaban terhadap kebutuhan keterampilan tenaga kerja dimasa depan agar mudah beradaptasi terhadap perubahan. Penyelarasan akan lebih tepat jika dilaksanakan dengan mengembangkan pembelajaran mandiri. Dengan merujuk pada pembelajaran yang berlangusng di abad XXI dimana diistilahkan 4Cs (four $C s$ ) berisikan komponen kemampuan berpikir kritis (critical thinking), kemampuan berkomunikasi (comunication), kemampuan kolaborasi (colaboration) dan kreativitas (creativity). Bruri (2019) menjelaskan dalam pembelajaran abad XXI untuk R.I 4 memiliki ciri antara lain fokus 
dan berkomitmen, pragmatis, independent dan menjadi pendidik dirinya sendiri. Pendekatan yang dapat dilakukan berupa menghilangkan pembelajaran yang berpusat pada guru saja, mengajak peserta didik untuk berpikir out of the box, menghentikan hafalan dan mengajak bagaimana memulai berpikir. Dalam konteks pembelajaran harus diciptakan peluang belajar dimana orang dapat mengembangkan kemampuan mereka untuk belajar secara mandiri melalui peran siswa melalui peran sisiwa merealisasikan proses pendidikan dari mendengarkan, mengamati hingga melakukan sesuatu. Orientasi pembelajaran pendektan OBE (Outcome Based Education) pembelajaran yang merujuk pada bukan tentang apa yang kami ajarkan akan tetapi tentang apa yang kamu pelajari, bukan tetang apa yang kamu ketahui, tetapi apa yang kamu kerjakan dari apa yang kamu ketahui.

Menyikapi perubahan yang terjadi dalam menghadapi paradigma pembelajaran RI 4.0 tentu perlu menyiapkan seorang guru sebagai aplikator dan mentor yang terlibat langsung dalam kegiatan proses pembelajaran agar mendapatkan hasil yang sesuai dengan diharapkan. Seorang guru yang profesional tidak sebatas memiliki kemampuan kompetensi teknis yang dimiliki namun guru dalam melaksanakan proses pembelajaran abad XXI diperlukan strategi dan inovasi seperti seorang entrepreneur sebagaimana mengalami revolusi industri sehingga seorang entrepreneur memiliki inovasi dengan berpikir kreatif dan efektif. Guru yang memiliki kemampuan layaknya entrepreneur diistilahkan teacherpreneur. Novan (2012) menjelaskan teacherpreneur tidak menjadikan guru sebagai pengusaha, tetapi menjadikan guru berjiwa kewirausahaan. Guru harus memiliki kompetensi yang baik, sikap kreatif dalam menyelenggarakan pembelajaran, dan efektif dalam menerapkan metode penyampaian pembelajaran sehingga peserta lebih cepat dalam memahami pembelajaran yang diberikan dan tidak membosankan. Guru kejuruan yang memiliki banyak potensi dan peran begitu besar. Guru kejuruan dituntut menyiapkan lulusan agar menjadi SDM yang unggul siap mengaplikasikan bidang keilmuan, dan memiliki pola pikir yang terus berkembang sebagaimana yang tertuang dalam tujuan pendidikan kejuruan.

Berdasarkan permasalahan dan pertimbangan pemikiran di atas, maka diperlukan kajian terhadap pengembangan model bagi peningkatan kualitas guru sekolah menengah kejuruan. Pengembangan model teacherpreneur merupakan rekonstruksi model yang telah dikembangkan sebelumnya dengan melihat perubahan yang terjadi mengenai revolusi industri 4.0 dan terjadi fenomena distrupsi suatu bidang kerja. Masukan dan perbaikan dari kajian model teacherpreneur yang terdiri dari rancangan model konseptual yang kemudian dapat diimplementasikan dan dilatih bagi guruguru SMK.

\section{Filosofi Pendidikan Kejuruan}

Pengembangan pendidikan vokasi tidak lepas dari filosofi atau aliran yang dianut, setidknya terdapat tiga filosofi yang terkenal dalam pendidikan kejuruan yang dijelaskan sebagai berikut:

\section{Esensialisme}

Aliran Esensialisme yang digagas oleh Charles A. Prosser (1913) memandang pendidikan vokasi merupakan sistem pendidikan yang membedakan pendidkan vokasi dari pendidikan akademik secara umum. Inti aliran filosofi ini merujuk pada prinsip social efficiency. Dimana pendidikan vokasi perlu diarahkan agar siswa mampu bekerja sesuai kebutuhan pasar tenaga kerja terutama dunia bisnis dan industri. Tugas sekolah dan guru berupaya menghadirkan situasi dunia kerja ke dalam kelas, sehingga sekolah perlu dilengkapi dengan sarana dan prasarana seperti mesin, peralatan dan fasilitas lainnya yang seperti diterapkan di dunia industri atau dunia kerja. Kondisi guru dikondisikan seperti keadaan di tempat kerja, dan memiliki 
pengalaman yang cukup dalam dunia industri sehingga mampu mendemontrasikan cara kerja sesuai realita yang terjadi. Melalui aliran ini kebutuhan sosial atau masyarakat menjadikan siswa memiliki pengalaman yang cukup berarti dan tidak perlu membutuhkan waktu lama untuk beradaptasi dilingkungan kerja nyata sehingga menjadikan siswa mahir dan berkompeten sesuai kebutuhan pasar kerja.

\section{Pragmatisme}

Salah satu tokoh yang terkenal dan menjadi rujukan dalam aliran filosofi ini adalah John Dewey (1913). Aliran filosofi menjelaskan bahwa pendidikan vokasi sebuah proses "meningkatkan" bukan untuk menerima kondisi manusia, kurikulum secara ideal didasarkan pada pengalaman siswa dan minat dan menyiapkan mereka untuk kehidupan masa depan. Aliran filosofi ini lebih fokus pada kebutuhan perkembangan individu siswa buka semata pada kebutuhan pasar kerja. Sekolah merupakan lingkungan spesial yang sesuai dengan lingkungan sosial masyarakat. Pendidikan vokasi dirancang mempersiapkan kehidupan siswa dimasa depan agar mampu memecahkan masalah dengan mengunakan kemampuan berpikir kritis. Metode mengajar yang ideal menurut aliran ini buahnya menekankan pada apa yang siswa pikirkan tetapi lebih pada membawa siswa untuk berpikir kritis, mengajar dituntut mengeksplorasi diri dari pada menjelaskan sesuatu materi. Menjadikan siswa mampu berpikir kritis lebih penting dari pada materi yang dipelajari. Belajar terjadi manakala seseorang terlibat dalam inkuiri keilmuan (scientific inquiry) pembelajaran menekankan pada learning by doing yang dibangun dari pengetahuan hasil pembelajaran sebelumnya serta menekankan pada penguasaan keterampilan berpikir tingkat tinggi (higher order thinking).

\section{Rekonstruksi}

Salah satu tokoh yang terkenal dan menjadi rujukan dalam aliran rekonstruksi adalah Miller \& Gregson (1999). Aliran filosofi ini dikembangkan dari gagasan sosial dan idealisme. Paham ini yang terlalu memberikan perhatian pada kebutuhan individu siswa dan rekonstruksi lebih menekankan pada kebutuhan sosial masyarakat dan sekolah harus menjadi agen perubahan. Pendidikan vokasi dalam aliran ini lebih diorientasikan pada penyiapan penyiapan situasi kerja yang demokratis terhadap situasi kerja yang tidak adil, diskriminan dan isu-isu kerja lainnya.

Berdasarkan ketiga aliran filosofi yang berkembang dan dijadikan acuan dalam menghadapi berbagai fenomena tuntutan perubahan yang terjadi seperti halnya sekarang ini terjadi perubahan paradigma dan teknologi yang begitu pesat. Pengembangan pendidikan vokasi dapat mengacu dari salah satu aliran filosofi diatas atau dapat juga menggabungkan keunggulan dari aliran filosifi tergantung tuntutan dan kebutuhan siswa , masyarakatdan pengguna lulusan. dari ketiga aliran yang telah dijelaskan diatas dapat digambarkan skema Segitiga Orientasi Filosofi Pendidikan vokasi sebagai berikut: 


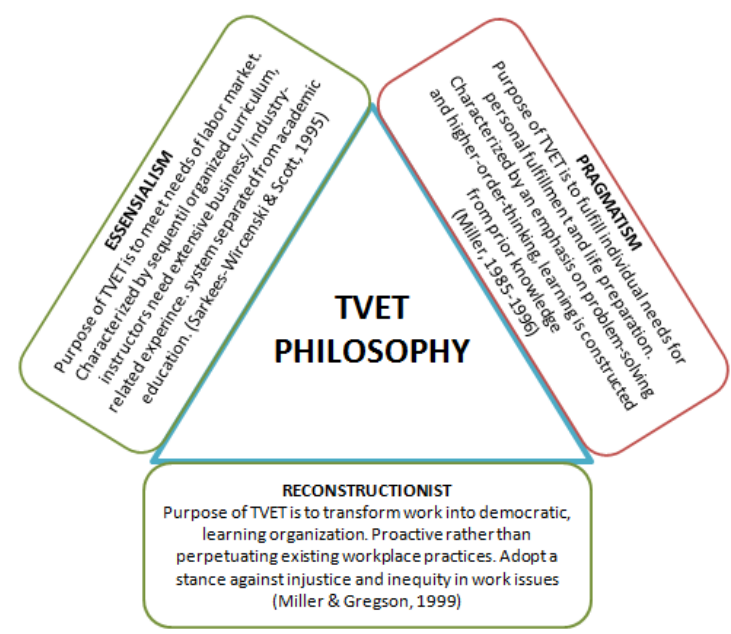

Gambar 1. Segitiga Orientasi Filosofi Pendidikan vokasi (Sutarto, 2019)

Pendidikan Vokasi di Era Disrupsi Revolusi Industri 4.0

Teori efisiensi sosial menyatakan bahwa dinamika perkembangan pendidikan vokasi selalu sejalan dengan dinamika perkembangan permasalahan dunia kerja. Perubahan konteks dunia kerja dan evolusi tuntutan dunia kerja masa kini dan masa depan menjadi variabel penting yang sangat berpengaruh terhadap sistem pendidikan kejuruan. Hal ini dikarenakan pendidikan kejuruan adalah pendidikan untuk pelatihan dunia kerja, pendidikan dan pelatihan untuk kemaslahatan karir kerja seluruh warga masyarakat.

Indonesia dan seluruh dunia dihadapkan pada tantangan perubahan lingkungan kerja dan cara kerja yang semakin disruptif, revolusi Industri 4,0. Renald Kasali memperkirakan pada tahun 2030 sekitar 2 miliar pegawai di seluruh dunia akan kehilangan pekerjaan. Pekerjaan-pekerjaan yang bertumpu pada otot berganti dengan teknologi robot. Kuli panggul di pelabuhan, supermarket, dan gudang tergeser oleh teknologi crane dan forklift. Pengelasan dan penyambungan komponen pada proses asembling atau perakitan digantikan dengan tangan robot yang tahan bekerja 24 jam tanpa henti. Demikian juga dengan pekerja-pekerja penunggu gerbang tol yang lambat laun digantikan dengan mesin-mesin e-tol (Sudira, 2019).

Di bidang pendidikan juga terjadi disrupsi luar biasa. Munculnya Massive Open On-line Course (MOOC) secara drastis akan mengubah cara pandang dan praksis pendidikan di seluruh dunia. Perkuliahan melalui internet on-line dan terbuka bagi siapa saja akan berlangsung semakin masif. Tugas guru dan dosen dimasa depan adalah menyediakan layanan e-learning dengan materi dan problematika kerja berkualitas tinggi. Secara on-line guru atau dosen membuka forum dan chatting bersama peserta didiknya dalam penguasaan kompetensi tertentu atau memecahkan masalah-masalah kerja yang kompleks. Peserta didik dapat berlatih sendiri menggunakan multimedia tutorial. Kekritisan berpikir dan kemampuan berkomunikasi menjadi darah segar pembelajaran era MOOC. Setelah peserta didik menguasai satu jenis kompetensi tertentu lalu mengikuti asesmen sertifikasi kompetensi atau sertifikasi profesi dan mendapat sertifikat berstandar nasional/ internasional untuk mendapat pekerjaan atau melakukan praktik layanan profesi tertentu seperti pendidikan notaris saat ini. Ruang-ruang belajar di era MOOC tidak lagi ruang kelas di dalam gedung kampus yang luas dan menjulang tinggi. Ruang belajar ada dalam ruang dunia maya (clouds) yang tidak berbatas tembok, waktu, dan jarak. 
Dengan cara seperti ini maka guru dan dosen akan bisa meningkatkan pembaharuan materi secara kontektual, otentik dan up-to-date berbasis masalah nyata di masyarakat atau dunia kerja. Inilah MOOC yang siap mendisrupsi sistem pendidikan.Saat ini ada tujuh tekanan luar biasa mendorong kebutuhan perubahan pembelajaran vokasional abad XXI yaitu: (1) Pengetahuan dan wawasan kerja; (2)
Ketrampilan kerja; (3) Sikap kerja; (4) Perangkat berpikir; (5) Gaya hidup digital; (6) Penelitian dan pengembangan pembelajaran; (7) Mental \& Moral kerja. Ketujuh tekanan ini secara simultan mendorong adanya kebutuhan model baru pembelajaran vokasional di abad XXI sebagaimana dalam gambar konvergensi pembelajaran vokasi abad XXI dibawah ini.

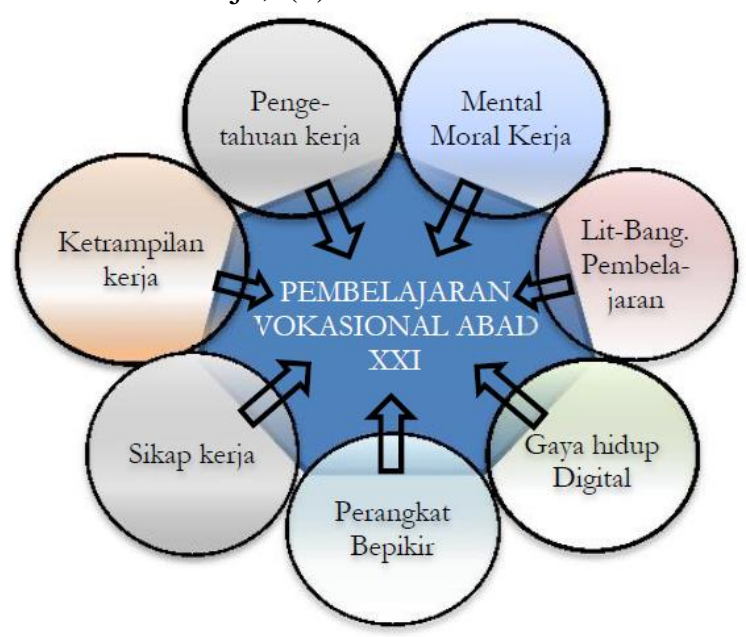

Gambar 2. Model Konvergensi Pembelajaran Vokasi Abad XXI (Sudira, 2019)

Pembelajaran vokasional abad XXI yang berkualitas adalah konvergensi dari variabel-variabel pengetahuan kerja, skill kerja, sikap kerja, perangkat berpikir, gaya hidup digital, penelitian dan pengembangan pembelajaran, mental dan moral kerja. Pengetahuan kerja semakin mudah dikembangkan melalui berbagai sumber belajar digital. Gaya hidup digital menjadi kebutuhan masyarakat belajar di abad XXI. Perkembangan komputer/laptop /smart phone yang semakin murah sangat mendukung kebutuhan akan perangkat elektronik tersebut. Laptop dan smart phone digunakan sebagai perangkat berpikir yang membantu manusia dalam belajar. Informasi telah melimpah dan kebutuhan pada satu hal yaitu moral juga menjadi pendorong perubahan pembelajaran abad XXI. Agar pembelajaran berkembang terus menerus maka penelitian dan pengembangan dalam hal pembelajaran terus dilakukan untuk peningkatan relevansi pembelajaran dengan kebutuhan dunia kerja bagi peserta didik. Proses pembelajaran membutuhkan iterasi pengembangan mental dan penggunaan mental untuk belajar.

Skill kerja, moral dan sikap kerja juga tetap mejadi pendorong bagi peningkatan kualitas pembelajaran vokasional Abad XXI. Penguatan disiplin, kejujuran, kerja keras, kerja tuntas, inisiatif, kemandirian, tanggungjawab, menghargai prestasi penting dikembangkan sebagai karakter. Kendati dunia ekonomi telah bertambah kuat dengan adanya era ekonomi berbasis pengetahuan maka skill kerja, baik skill motorik maupun skill kognitif tetap terus dilatihkan. Skill menggunakan perangkat IT menjadi syarat mutlak peningkatan kompetensi dalam belajar. Skill lainnya termasuk skill memanfaatkan sumber daya pembelajaran juga menjadi bagian penting pendorong perubahan pola pembelajaran vokasional abad XXI.

Inovasi kerja di era digital berubah setiap saat. Perubahan sikap dibutuhkan dari peduli teknologi (technological awareness) ke melek teknologi (technological literacy) lalu menjadi berkapasitas atau memiliki kapasitas 
teknologi yang baik (technological capacity) dan siap menerapkan teknologi digital secara kreatif (technological creativity). Hal ini merupakan permasalahan dasar pembelajaran vokasional Abad XXI. Semuanya harus didasari pada kemauan dan kemampuan pengambilan keputusan (technological critism) tentang teknologi apa yang akan digunakan, bagaimana model penerapannya, dan mengapa teknologi itu dipilih dan diterapkan. Kapabilitas semacam ini merupakan hal yang penting di era digital.

Cara-cara kerja baru berkembang semakin random dan jamak. Cara menyelesaikan masalah kerja bukan tunggal lagi. Kolaborasi kerja lintas bidang, lokasi geografis tanpa batas, lintas etnis, lintas suku semakin berkembang. Pekerja baru abad XXI membutuhkan tim yang kuat dan kompak, penuh tekanan waktu, membutuhkan kompetensi teknologi, sains dan ketrampilan sosial budaya- ekonomi yang semakin tinggi, mampu mengelola dan memecahkan masalah, ekspert dalam menggunakan informasi dan data secara akurat. Perubahan struktur kerja dan permasalahan kerja yang demikian membuat lembaga layanan masyarakat, perusahaan jasa dan industri semakin merampingkan organisasinya yang berdampak pada pengurangan personel kerja. Hal ini dimaksudkan agar organisasi kerja semakin efisiensi, gesit, kompetitif, inovatif, dan terus menghasilkan nilai tambah.

Kurikulum dan pembelajaran vokasional harus terus-menerus diperbaharui sesuai perkembangan, perubahan, dan inovasi dunia kerja agar selalu link dan match dengan kebutuhan dunia kerja baru. Tidak terjadi kesenjangan antara kompetensi lulusan dengan kebutuhan dunia kerja, apalagi miss-match skill yang dapat menyebabkan transisi panjang dari sekolah ke dunia kerja. Pembelajaran vokasiabad XXI membutuhkan isi materi skill berkualitas tinggi dan juga strategi pembelajaran yang jitu sesuai tuntutan karakteristik materi skill, kompetensi, karakter peserta didik, dukungan fasilitas pembelajaran, dan dukungan jaringan lintas lembaga secara global.

\section{METODE}

Penelitian ini merupakan kajian secara ilmiah mengenai model teacherpreneur yang ada mengenai perubahan yang terjadi termasuk dalam proses pembelajaran di era revolusi industri 4.0 dan distrupsi. Pendekatan yang digunakan dalam penelitian ini menggunaan deskriptif (descriptive reasearch). Kajian ini mendeskripsikan secara ilmiah berdasarkan kajian literatur yang ter up date tentang inovasi dalam pembelajaran abad XXI terhadap model teacherpreneur guna menyiapkan lulusan LPTK sebagai pencetak guru di sekolah kejuruan/ vokasi menjadi guru yang unggul.

\section{HASIL DAN PEMBAHASAN}

Prihadi (2016) menjelaskan model teacherpreneur yang telah dikembangkan terdiri dari tiga pilar yaitu pilar kompetensi, pilar kreativitas dan pilar efektivitas. Seluruh komponen tersebut tidak dapat dipisahkan antara satu dan lainnya. Untuk menghadapi tantangan abad XXI dan disrupsi perludilakukan berbagai inovasi dalam berbagai momponen yang terlibat proses pembelajaran. Tidaklah cukup sebatas dilihat dari kompetensi saja, yang selama ini sering dilatihkan dalam berbagai kegiatan. Inovasi dan integrasi antara beberapa komponen meliputi kreativitas dan keefektifan dari seorang guru dalam pembelajaran abad XXI sangat penting dan penggunaan berbagai macam sumber daya dalam kegiatan belajar mengajar.

Seorang guru vokasi diwajibkan memiliki kompetensi yang baik dalam bidang keahlian mengajar. Kompetensi yang telah disyaratkan dalam undang-undang meliputi kompetensi pedagogik yang berkaitan dengan cara atau kemampuan guru dalam mengajarkan ke siswa, kompetensi sosial berkaitan dengan membina hubungan guru terhadap siswa dan orangtua siswa/wali serta masyarakat, kompetensi kepribadian berkaitan dengan 
tuntutan pribadi yang harus dimiliki seorang guru, dan kompetensi profesional berkaitan dengan penguasaan guru terhadap materi yang diajarkan. Pilar kreativitas guru merupakan kemampuan menyelesaikan pembelajaran dengan baik yang ditunjukkan oleh peningkatan hasil belajar. Artinya guru menggunakan/ mendayagunakan sumber daya yang ada dalam kegiatan pembelajaran untuk meningkatkan kemampuan baik itu dengan mengubah lingkungan, menggunakan media/alat bantu, atau dapat juga mengadakan kegiatan di luar kelas. Kreatifitas tidak harus mahal, justru semakin sederhana dan memudahkan dalam pemahaman pembelajaran maka akan semakin baik. Hal ini diperkuat penjelasan Sudira (2018) yang memaknai Guru yang kreatif menjadi kunci keberhasilan pembelajaran vokasi abad XXI. Tanpa guru kreatif sulit rasanya pembelajaran vokasional meningkat kualitasnya. Kurikulum, sarana prasarana yang memadai, bahan yang cukup di tangan guruguru kreatif akan dihasilkan proses pembelajaran yang kreatif, lulusan yang kreatif dengan skill kerja yang tinggi. Komponen efektivitas merupakan kesesuaian antara pelaksanaan tugas dengan sasaran yang ditujuan. Artinya, apa saja yang digariskan dalam kegiatan pembelajaran terpenuhi semua dengan tepat waktu ber-langsungnya pembelajaran yang tuntas, kesesuaian materi dengan apa yang terjadi dilapangan.

Menyikapi perubahan yang terjadi dimana cara kerja baru semakin berkembang dan semakin random dan jamak maka dibutuhkan kolaborasi lintas bidang yang bukan lagi meliha dari satu tinjauaan, akan tetapi kolaborasi dengan tim yang kuat dan kompak sangat penting. Kemampuan kolaborasi sangat dibutuhkan untuk menghadapi perubahan yang terjadi dalam pembelajaran abad XXI . Bekerja di abad XXI tidak ada lagi pekerjaan menyendiri, lepas dari orang lain dan sistem. Bekerja di abad XXI bekerja dalam sistem dan tim. Bekerja sebagai proses interaksi sosial antar individu, interaksi manusia dan mesin, interaksi manusia dengan perubahan teknologi. Teknologi dalam hal ini bermakna keinginan (volition), proses, peralatan, sistem organisasi. Mengajar dan mendidik di sekolahsekolah kejuruan juga demikian kondisinya. Mendidik anak mewujudkan standar kompetensi lulusan melalui pembelajaran adalah proses kolektif diantara sesama guru. Semua guru harus menyadari bahwa tugas mendidik yang dilakukan adalah tugas tim. Pekerjaan sebagai pengajar di abad XXI membutuhkan kemampuan kolaborasi kerja yang intensif antar sesama guru, antara guru dengan praktisi di dunia kerja, dan antara guru dengan peserta didik. Eksistensi Musyawarah Guru Mata Pelajaran (MGMP) penting sekali dikembangkan dalam membangun kreativitas guru. (Sudira, 2019).

Konsep baru pembelajaran vokasi mengarah pada pembentukan kemampuan atau kompetensi lulusan untuk dapat memecahkan masalah dengan berpikir kritis sesuai kompetensi dan pengenmbangan diri, berpikir kreatif, efektifitas bekerja dan dilakukan secara kolaborasi oleh karena itu pembelajaran vokasi Abad XXI membutuhkan pengembangan kemampuan kerja sama dalam memecahkan masalah. Maka sudah saatnya diperhatikan bahwa pembelajaran individual mulai dikurangi proporsinya dan melibatkan banyak bentuk penugasan untuk berkolaborasi dengan penugasan yang membutuhkan pemikiran tingkat tinggi. Walaupun demikian tetap pengembangan kompetensi bersifat individu dan fungsional dalam kelompok.

Menyikapi hal diatas tiga pilar yang ada dalam teacherpreneur belum lah cukup untuk dikatakan dan menjadikan seorang guru dapat secara holistik perlunya penambahan pilar kolaborasi dalam model teacherpreneur. Berikut ini disajikan model teacherpreneur sebelum dan telah ditambahkan sebagaimana pada Gambar 3 


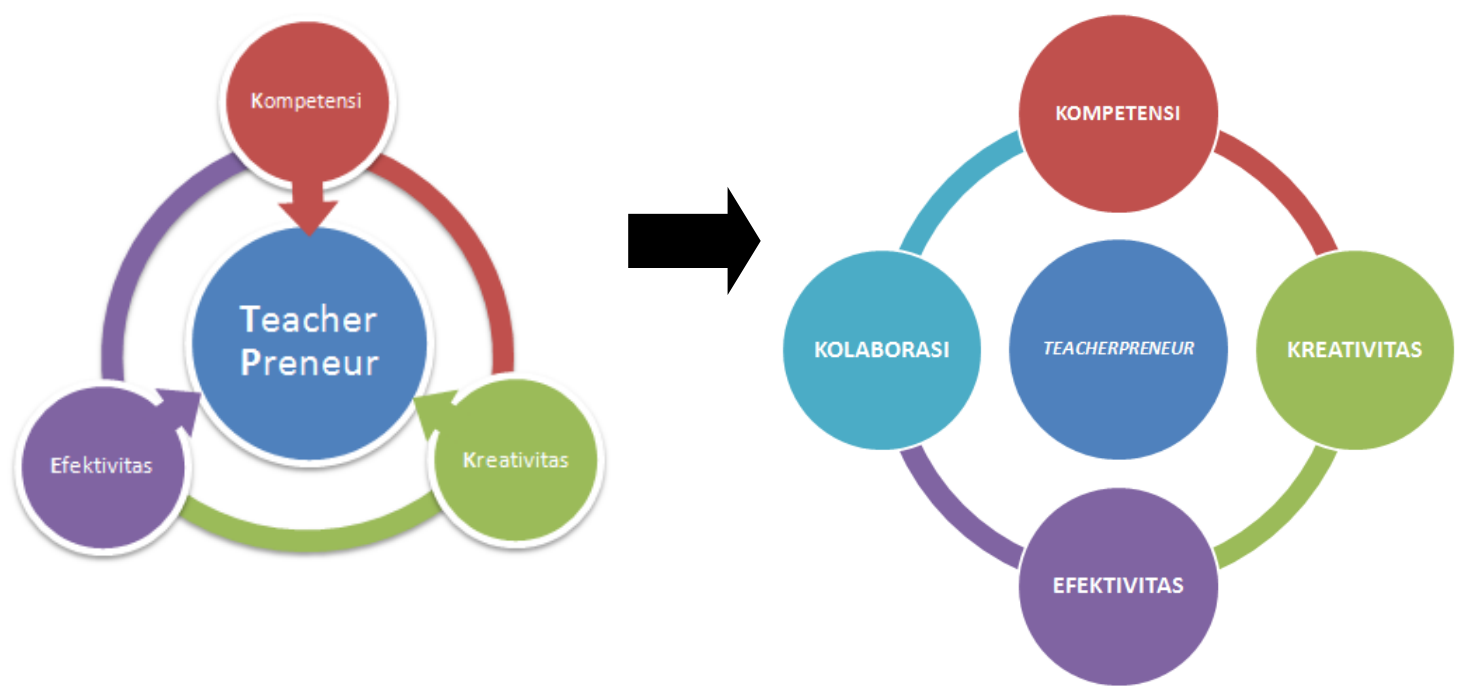

Gambar 3. Model Teacherpreneur awal dan Model Teacherpreneur penambahan

Model teacherpreneur ini diharapkan dapat dijadikan acuan dalam pengembangan keprofesionalan guru vokasi dalam menyiapkan SDM yang unggul dan sebagai strategi mengisi peta jalan pengembangan SMK hingga Tahun 2045 sebagai dampat revitalisasi SMK yang berlangsung.

\section{SIMPULAN}

Berdasarkan hasil kajian model teacherpreneur dapat disimpulkan sebagai berikut, Pertama, grand design model teacherpreneur pada SMK terdiri dari: (1) empat pilar penyusun yaitu pilar kompetensi, pilar kreativitas, pilar efektivitas dan pilar kolaborasi. Kedua, kemampuan berkolaborasi penting untuk dilatih guna meringankan, mempercepat tuntutan pembelajaran di abad XXI.

\section{DAFTAR RUJUKAN}

Novan, A.W. (2012). Teacherpreneurship. Yogyakarta: AR-RUZZMEDIA.

Prihadi, W. R., \& Sofyan, H. (2016). Pengembangan model teacherpreneur pada sekolah menengah kejuruan. Jurnal Pendidikan Vokasi, 6(2), 230-240.
Sudira, P. (2018). Metodelogi Pembelajaran Vokasional Abad XXI Inovasi, Teori, dan Praksis. Yogyakarta: UNY.

Sudira, P. (2016). TVET ABAD XXI Filosofi, Teori, Konsep dan Strategi Pembelajaran Vokasional. Yogyakarta: UNY.

Parjono. (2019). Reorientasi Pendidikan Kejuruan untuk Pembangunan Daerah dan Tantangan Industri Generasi Empat. Orasi Ilmiah Disampaika Dalam Rangka Dies Natalis Fakultas Teknik UNY. Yogyakarta: UNY.

Triyono, M. B. (2019). Penyelarasan Pembelajaran Vokasi Untuk Revolusi Industri 4.0. Pidato Pengukuhan Guru Besar UNY .

Sutarto, (2019). Filosofi dan Pengembangan Kurikulum Pendidikan Vokasi dalam Era Disrupsi. Pidato Pengukuhan Guru Besar UNY. 